\title{
'Lillebrorsyndromet' Nye hierarkier i den tværmediale nyhedsproduktion
}

\author{
AF JANNIE MØLLER HARTLEY
}

\section{Resumé}

Danske medieorganisationer er i stigende grad blevet til mediehuse, der fordrer nye strategier for journalistisk samarbejde på tværs af medieplatforme. I artiklen undersøges produktionskulturerne i tre større mediehuse i Danmark i lyset af konvergensteori og idealer om tværmedialt, redaktionelt samarbejde. Undersøgelsen viser, at dette samarbejde kan ses som et kontinuum, hvor man i den ene ende finder platforme, der hovedsagelig producerer nyheder, og i den anden ende platforme, der mere reproducerer og distribuerer nyheder. Det vises, at det er netredaktionerne, der typisk får den distribuerende rolle - de bliver "lillebror" i mediehuset. Dette har konsekvenser for den journalistiske specialisering og for de statushierarkier, der præger mediehusenes redaktionskulturer: En 'usynlig mur' rejses mellem de journalister, som gives tid til at udvikle egne historier, og dem, som hovedsagelig opdaterer og reproducerer indhold fra én medieplatform til en anden.

\section{Indledning}

En mandag morgen i marts 2010 drager en gruppe af redaktører og journalister fra Nordjyskes netredaktion på turné til de nordjyske lokalredaktioner. De skal præsentere projektet "Vi skruer op for nettet". De har chefredaktøren med, da de skal møde den 
første redaktion af avisjournalister, som skal præsenteres for det nye projekt.

Da holdet går ned mod mødelokalet, taler repræsentanterne fra netredaktionen om, at det er godt, at chefredaktøren er til stede, da det giver mere 'pondus'. De taler også om 'kamp' og om, hvordan de forestiller sig, at avisens medarbejdere vil stille masser af kritiske spørgsmål til, hvad der nu skal ske. Da de kommer ind i lokalet, hvor der er en del pladser ledige, da kun et par avisjournalister allerede er dukket op, sætter holdet sig sammen på den ene side og gør plads til, at chefredaktøren kan sidde ved siden af dem. De kommer dermed til at sidde direkte over for deres kollegaer fra avisen. De fire og chefen har forberedt deres oplæg på forhånd, og chefredaktøren indleder med den overordnede strategi for Nordjyskes udvikling på netplatformen og behovet herfor. Netredaktøren fortsætter og forklarer i detaljer, hvordan de ser, at samarbejdet kan fungere. "Det handler ikke om at flytte ressourcer til netplatformen, men om at bruge de eksisterende ressourcer bedre," siger han flere gange. Souschefen fra netredaktionen fortæller, hvordan journalisterne gerne i deres skrivemåder må tænke mere på Nordjyske.dk, og han har statistikker med, som illustrerer hans pointer om, hvordan læserne på Nordjyske.dk opfører sig. Netredaktøren supplerer og påpeger, at læserne på Nordjyske.dk ikke bryder sig om det, han kalder 'systemhistorier'. Han fortæller, hvordan en historie om et ellers kedeligt bestyrelsesmøde i et lokalt vandværk kunne få masser af læsere, da en kendt håndboldspiller havde holdt et oplæg, hvorefter der kunne vinkles på dette. "Snyder man ikke læserne," lyder det fra en avisjournalist. "Vi skal turde være lidt skarpe, men naturligvis uden at snyde læseren," lyder svaret. Men det er først, da repræsentanten for annonceafdelingen har holdt sit oplæg, at spørgsmålene for alvor starter. Avisjournalisterne vil vide, hvor mange penge, man får for et klik. Og de vil også vide, hvor meget 11 journalister på en netredaktion reelt kan dække? "De kan især dække de løbende nyheder. Og de kan hjælpe, hvor der er brug for det og ellers lede efter citathistorier," er svaret.

På en række af møder gentages det samme oplæg, og de fire oplægsholdere sidder på række over for de spørgende avisjournalister. De fleste steder er stemningen imødekommende, men på et par redaktioner flyder oplæggene over i opstemte debatter 
om ekstra arbejde uden ekstra løn. Da holdet forlader stederne og siger farvel til kollegerne, taler netredaktionens ambassadører om, hvordan det "jo er en proces, som kommer til at tage tid", og hvordan de nye "netpartnere", som skal have ekstra undervisning $i$ at skrive og arbejde med nettet som platform, formentlig kan gøre en forskel.

Projektet "Vi skruer op for nettet" og selve præsentationen af projektet i mediehuset Nordjyske er et illustrativt eksempel på, hvordan mediehuset Nordjyske på linje med andre mediehuse kæmper for at få styrket sin position som konvergeret mediehus ved at få journalister til i højere grad at arbejde tværmedialt mens journalisterne er mere interesserede i at bevare deres specialisering i en bestemt medieplatform - i dette tilfælde avisen. Denne artikel præsenterer en analyse af tværmedial nyhedsproduktion i tre forskellige mediehuse, Politikens Hus, Danmarks Radio og Nordjyske Medier. I alle tre huse har medieorganisationernes strategier for tværmedialt samarbejde mellem journalister fra forskellige og hidtil adskilte medieplatforme resulteret i nye hierarkier i nyhedsproduktionen. Hierarkier, der viser, at tværmedialt samarbejde og modstanden mod dette kan forstås i lyset af redaktionernes og journalisternes kamp om at opretholde en producerende rolle. Artiklens centrale argument er således, at begreber som produktion og distribution kan udvide det eksisterende begrebsapparat inden for den eksisterende litteratur om konvergens og flermedial nyhedsproduktion, således at konvergens ikke ses som en konstant bevægelse mod et endeligt mål om øget samarbejde på tværs i nyhedsorganisationen, men som forskellige grader af produktion og distribution af nyhedsstoffet på de forskellige redaktioner. For at artiklens analytiske bidrag fremstår tydeligt, er det derfor nødvendigt kort at gennemgå litteraturen om konvergens. Derudover præsenteres de metodiske valg, jeg har foretaget.

\section{Forskning i konvergens og tværmedial nyhedsproduktion}

Konvergens omhandler alt fra journalisternes flermedialitet til krydspromovering af journalistisk stof på flere platforme og produktion af journalistisk stof til flere platforme. Meget af littera- 
turen omhandler journalisternes modstand mod konvergensen, ofte metodisk analyseret på baggrund af spørgeskemaundersøgelser i, hvad man kan betegne som netjournalistikforskningens 2. fase (se Hartley, 2011). Senere kom en række analytiske bidrag fra forskningen i form af teoriudvikling af konvergens- og tværmedialitetsbegreberne. Dailey et al. (2005) foreslår et konvergens kontinuum med fem stadier. På det første stadie kan man observere krydspromovering af stof på tværs af platforme. Det andet stadie beskrives som 'cloning', hvilket indebærer deling af noget indhold. På det tredje stadie 'coopetition ' foregår der stadig en del konkurrence mellem platformene, mens denne er forsvundet på det fjerde stadie, hvor indhold deles på kryds og tværs. Ved fuld konvergens på det femte stadie er platformene smeltet sammen, og der produceres nyheder flermedialt (Dailey et al., 2005:152).

Idealet om den konvergerede nyhedsproduktion inkluderer således øget samarbejde på tværs i organisationen og signifikante, organisatoriske ændringer (ibid.) - noget Deuze peger på, er en særlig udfordring for det ellers noget individuelle, journalistiske nyhedsarbejde (Deuze, 2004:146). Det er i det lys, at vi bør se journalisternes modstand mod den tværmediale nyhedsproduktion, forstår vi.

Helena Norman peger på baggrund af interview med journalister fra web og avis samt redaktører i to svenske mediehuse, at konvergens implementeres forskelligt i forskellige medieorganisationer. Det ene medie anstrengte sig for netop ikke at publicere avisen på netmediet, mens den anden medieorganisation havde en blanding af stof fra avisen og stof produceret udelukkende til nettet (Norman 2008:157). Journalisterne havde i undersøgelsen en generel modvilje mod flermedialitet og det at skulle producere til flere medieplatforme og beretter om et højere tempo og mere stress (Norman 2008:156-157).

Anja Bechmanns studier (2006 og 2009) i et mere medieteknologisk perspektiv og med danske casestudier viser, at mediebegreber er variable størrelser. Snarere end at være knyttet til bestemte objekter bruges de som struktureringer eller fortolkningsmønstre i forskellige materialiteter og kontekster (Bechmann 2006:23). Hun viser, at medier ikke konvergerer eller divergerer mod et slutpunkt eller med et udgangspunkt. Medie- 
fænomener og mediebetegnelser spreder og fordeler sig på forskellige niveauer. Med udgangspunkt i eksempler på net-tv, netradio og netmedier viser Beckmann, hvordan netproduktionerne udvidede forståelsen af tv, radio og avis til også at omfatte nye typer af indhold, formmæssige udtryk samt materialitet (ibid.)

Erdahl skelner mellem crossmedia-kommunikation og crossmedia-produktion, hvilket er nyttigt for det analytiske arbejde præsenteret i denne artikel. Hvis en journalistisk artikel eller et indslag er produceret i samarbejde mellem reportere fra to eller flere platforme enten i researchfasen eller via deling af indhold, kan vi ifølge Erdahl tale om en crossmedia-produktionsproces (Erdal 2011:217). Det fremstår nyttigt at udvide vores forståelse af den konvergerede nyhedsproduktion til at omfatte forskellige dele af den journalistiske produktionsproces.

En kritik af undersøgelserne på et empirisk niveau er, at de ofte konkluderer, at journalisternes personlige holdninger er skyld i den 'utilstrækkelige' konvergens, eller at ledelsesstrategier om effektivisering skræmmer journalisterne, som derfor stiller sig på bagbenene. Dette skyldes overordnet, at resultater ofte baseres på spørgeskemaundersøgelser med journalisterne eller interviews med redaktører og mediechefer. Derfor kan de ikke give os svar på, hvorfor netjournalisterne føler sig som 'andenrangsborgere', men blot konstatere, at det gør de, og at det stresser dem.

For det andet kan konvergenslitteraturen kritiseres på et begrebsmæssigt niveau for at have implicit som normativt ideal, at medieorganisationer bør bevæge sig mod stadig større konvergens, og modstanden fra journalisterne angives som årsagen til, at medieorganisationerne ikke har nået det mål.

Frem for at tale om forskellige produktionskulturer, der samarbejder i større eller mindre grad, er min pointe med artiklen her at vise, at crossmedia-produktion analytisk kan ses i relation til forskellige former for journalistisk specialisering på tværs af platforme, genrer, emner og målgrupper. Konvergens- og crossmedia-begrebet tager ikke højde for, at mediehusenes fokus på de forskellige medieplatforme og samarbejde på tværs fødes ind i en historisk organisering, hvor andre former for specialisering udviskes eller styrkes ved mediehusenes forskellige konvergensstrategier. Et sådant perspektiv kan styrkes ved at inddrage kritisk sociologisk teori, og i denne artikel benyttes Bourdieus feltteori. 
Via et fokus på magt og på relationerne mellem medieplatforme og medieorganisationer og de respektive kampe om magt formår feltteorien at rette forskerens blik mod det komplekse samspil mellem medieplatformene og sætte de interne kampe om læserne og om, hvad der udgør 'den gode netjournalistik', i et nyt og mere analytisk lys.

Feltperspektivet åbner op for en analyse af netjournalisternes modsatrettede strategier og positioneringer, som åbner vores øjne for det spil med forskellige værdiindsatser og våben, journalister og redaktioner kan benytte sig af.

\section{Metode og valg af cases}

Flere forskere har på det seneste peget på, at der er brug for undersøgelser af netjournalistisk praksis (Domingo, 2006; Boczkowski, 2004b), og at produktionsstudier i det hele taget er en mangel også i dansk medieforskning (Mortensen, 2000:31; Lund, 2001:83; Schultz 2006:64). Analyserne i denne artikel baserer sig således på et studie af den journalistiske praksis, hvor den primære metode er etnografisk feltarbejde i 3 mediehuse, som fungerer som casestudier.

Valget af Pol.dk, Dr.dk og Nordjyske.dk repræsenterer en 'mest-forskellig'-tilgang (Yin, 2009). Casenes ligheder og forskelligheder - blandt andet med hensyn til størrelse, historie og dækningsområder - var nyttige til blandt andet at analysere forskelle og ligheder på tværs af de tre cases.

Feltobservationerne, der fandt sted fra maj til november 2009, varede omkring 6 uger hvert sted. I 2010/11 vendte jeg tilbage i en uge til hver af de tre medieorganisationer. Undervejs i observationsforløbet deltog jeg i redaktionsmøder og lignende, ligesom jeg fulgte enkelte journalister i det daglige arbejde og noterede ned undervejs. Jeg foretog 35 interviews med nuværende netjournalister, radio-, tv- og avisjournalister og redaktører. Interviewene varede mellem 20 og 70 minutter (gennemsnitlig ca. 40 min). Formålet med interviewene var dels at få sat ord på nogle af de journalistiske rutiner, jeg havde observeret i det daglige arbejde, dels at få journalisterne til at sætte ord på de hierarkier, jeg ligeledes kunne observere, når netjournalister forsøgte 
at positionere sig som 'rigtige' journalister og opnå anerkendelse både internt i medieorganisationen og eksternt blandt andre netjournalistiske kollegaer.

Tabel 1. Forskelle og ligheder på de tre valgte cases

Tallene stammer fra en analyse af indholdet på syv større netmedier (Hartley 2011).

\begin{tabular}{|l|l|l|l|}
\hline Mediehus/model & Politiken & DR & Nordjyske \\
\hline Mediemodel & Print/online & $\begin{array}{l}\text { Radio/television/ } \\
\text { online/ } \\
\text { 24-timers nyheds- } \\
\text { kanal }\end{array}$ & $\begin{array}{l}\text { Print/radio/ } \\
\text { online } \\
\text { /24-timers } \\
\text { nyhedskanal }\end{array}$ \\
\hline Forretningsmodel & Kommerciel & Public Service & Kommerciel \\
\hline Dækning & National & $\begin{array}{l}\text { National og } \\
\text { regional }\end{array}$ & Regional \\
\hline Konvergensmodel & $\begin{array}{l}\text { 45 procent egen- } \\
\text { produktion til nettet, } \\
\text { mest centraliseret } \\
\text { produktion til nettet }\end{array}$ & $\begin{array}{l}18 \text { procent egen- } \\
\text { produktion: både } \\
\text { centraliseret og } \\
\text { decentraliseret } \\
\text { produktion }\end{array}$ & $\begin{array}{l}\text { 8 procent } \\
\text { egenproduktion } \\
\text { til nettet: mest } \\
\text { decentraliseret }\end{array}$ \\
\hline
\end{tabular}

\section{Nyhedsveje i mediehusene}

I det følgende beskriver jeg, hvordan nyhedsproduktionen er organiseret og fordelt mellem de forskellige platforme og redaktioner i de tre mediehuse. En deskriptiv gennemgang af de veje, leveringerne bevæger sig i mediehuset kan illustrere de tre mediehuses forskellige konvergensstrategier. Målet med både at analysere tværmedialt samarbejde (eksempelvis hvor journalister producerer en historie til flere medieplatforme) i organisationerne og de tilfælde, hvor der ikke foregår samarbejde, er at opnå en mere nuanceret forståelse af betydningen af konvergens i de enkelte mediehuse.

\section{Organisering af nyhedsproduktionen i Politikens Hus}

I Politikens Hus sidder netredaktionen adskilt fra avisredaktionen. Der er hovedsagelig tale om, hvad Erdahl betegner kommunikativ crossmedia (Erdahl, 2011), idet de enkelte redaktioner er 
selvkørende, og redaktionsmøderne benyttes til at lede og fordele arbejdet mellem dem. Men som hovedregel producerer netjournalister til nettet og avisjournalister til avisen.

Pol.dk har også en række underredaktioner tilknyttet. Disse producerer også hovedsagelig til nettet, men Tjek- og Ibyenredaktionerne producerer også til weekendens tillæg i avisen. Selve netredaktionen er inddelt i en række underområder, som nogenlunde svarer til de faglige inddelinger, vi kender fra en avis. Således er et par journalister beskæftiget med kultur, andre med sport, mens Tjek-redaktionen tager sig af forbrugerstoffet, og Ibyen beskæftiger sig med kultur i form af anmeldelser og anbefalinger. At produktionen er inddelt efter de to medieplatforme net og avis kan betegnes som en medicer organisering, hvor mediehuset vægter en specialisering i de enkelte medieplatforme. Og at både avisen og nettet dermed har medarbejdere med forskellige faglige områder kan betegnes som en indholdsmoessig organisering efter forskellige temaer og fagområder. Pol.dk publicerer dog også stof fra avisen på nettet, mens det er sjældent, at avisen publicerer stof fra netredaktionen (Hartley, 2011). Dog indgår netartiklerne til tider som noter i avisens nyhedsbånd, jf. den stiplede linje i figuren (før omlægningen af Politiken i 2011).

Figur 1. Skitse af leveringsvejene på Pol.dk

\section{POLITIKEN}

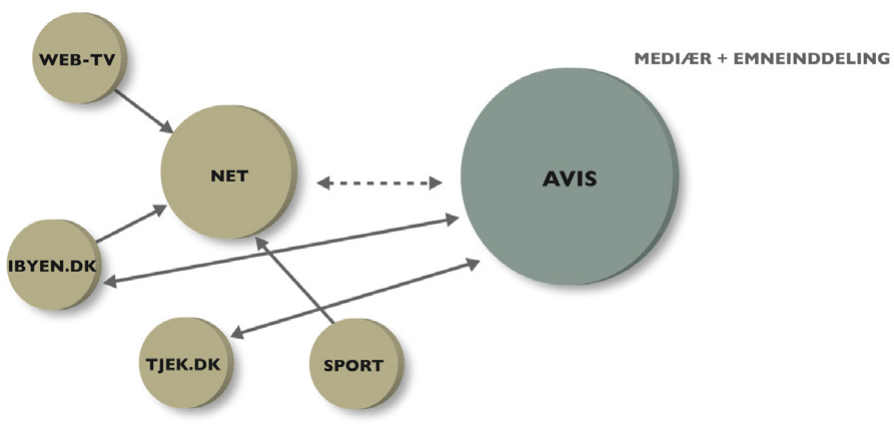

Organisering af nyhedsproduktionen i Danmarks Radio

I Danmarks Radio er netredaktionen i 2008 en selvstændig redaktion, mens den i 2010 er blevet en del af en større nyheds- 
redaktion. Hvor de altså før havde en medicer organisering, får de nu, hvad man kan betegne som en genremoessig organisering, idet nyhedsredaktionen hovedsagelig skal producere i genren nyheder, mens andre genrer produceres andre steder i DR-huset.

Hver redaktion i DR har således fast eller løst dedikeret én eller flere medarbejdere til dagens levering til Dr.dk. Netredaktionen får hovedsagelig sit nyhedstof fra andre platforme, men heraf kun en begrænset del fra tv-platformen. Men netredaktionen har også sine egne medarbejdere som nævnt ovenfor, som også bearbejder indhold fra resten af huset (før omlægningen i 2010).

Dr.dk har altså både en medicer organisering, hvor journalistister producerer til forskellige medieplatforme, og en indholdsmoessig organisering, idet DR samtidig har redaktioner såsom Penge, Udland og Sundhed, som også leverer til nettet. Endvidere leverer også DR's Regioner til nettet, og vi kan således tilføje endnu en organisatorisk inddeling. Denne kan betegnes som en geografisk eller nichemoessig organisering og dækker over en organisering af specialisering i produktion og distribution af nyheder til forskellige, specifikke målgrupper. Men som pilene i figur 2 angiver, trækker netredaktionen hovedsagelig nyhedsstof ind fra de forskellige redaktioner, mens det er sjældent, at de leverer stof til de faglige redaktioner eller Regionerne.

Figur 2. Skitse af leveringsvejene på Dr.dk (efter etableringen af Nyhedsredaktionen i 2008)

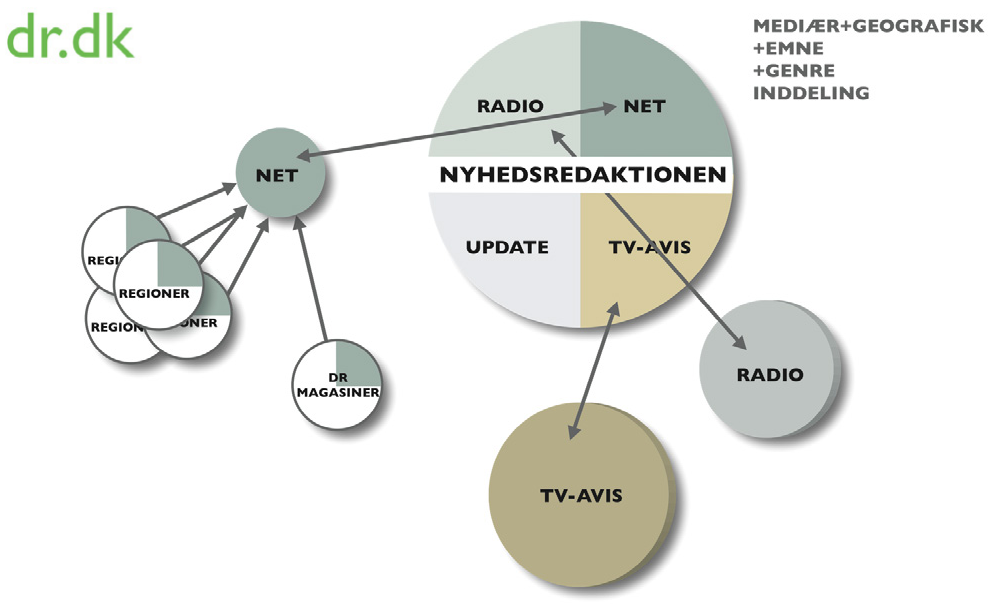




\section{Organisering af produktionen i Nordjyske Medier}

Ligesom i de to andre mediehuse går trafikken af produktionen mellem platformene i Nordjyske Medier hovedsagelig den ene vej. Også her er der etableret en nyhedsredaktion ved navn 'Nyhedsmotoren', hvor en jourhavende fra hver af de såkaldte 'hurtige medier' befinder sig. Også på Nordjyske ser vi den genremoessige organisering, idet Nyhedsmotoren særligt tager sig af nyhedsdækningen. Dette er dog godt blandet med den medicere organisering, idet Nyhedsmotoren er besat med en jourhavende fra hver platform. Journalister fra lokalredaktionerne og fra indholdsgrupperne (emnemæssigt inddelt eksempelvis i erhverv og sport) sender løbende artikler til den jourhavende på netredaktionen, som herefter videresender dette til tv-jour og til radio-jour. Ofte vurderer disse tre jourhavende i fællesskab, hvad der egner sig til radio, mens tv-platformen er afhængig af indslag produceret af avisens journalister eller af netplatformens journalister, når der er en større sag, der skal dækkes herfra.

Figur 3. Skitse af leveringsvejene på Nordjyske.dk

\section{NORDJYSKE.DK}

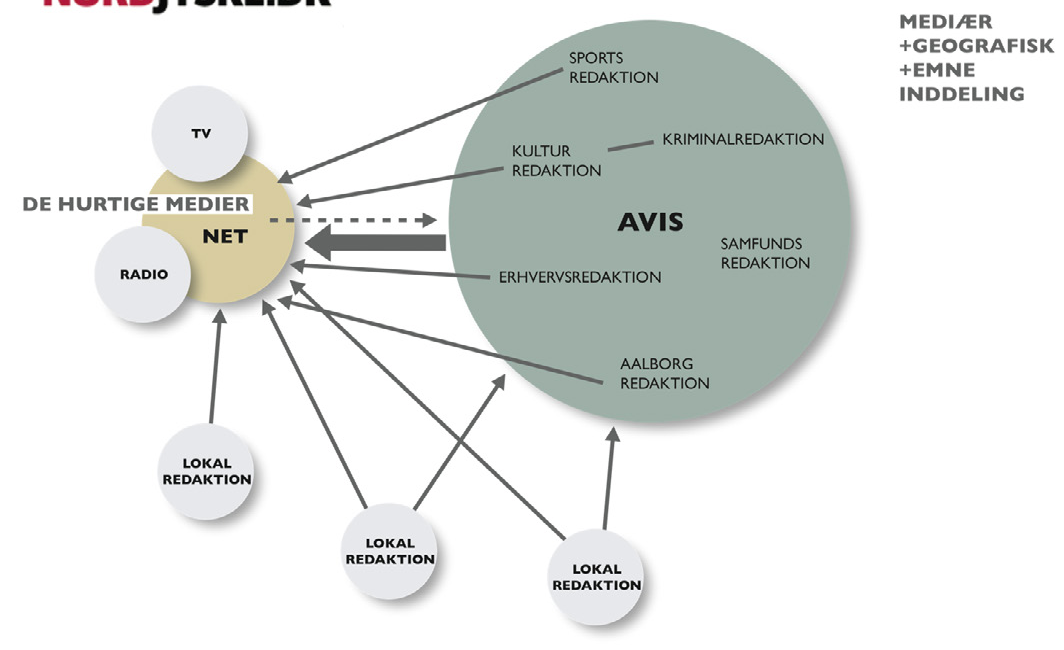

I den periode jeg følger Nordjyske.dk, går inddelingen (ligesom i DR) fra at være hovedsagelig medicer inddeling til et øget fokus på en mere genremoessig inddeling. 'De hurtige nyheder' skal nu 
især og endnu mere end før stå for nyhederne, mens de lokale og indholdsgrupperne skal stå for mere baggrundsagtigt stof til avisen, men også skal levere især nyheder til netplatformen. Netredaktionen bliver også samlet set større med flere medarbejdere direkte dedikeret til nyhedsproduktionen. Og som figur 3 viser, bevæger trafikken af redaktionelt stof sig, ligesom i Politikens Hus og DR, hovedsagelig den ene vej, og også her er crossmedia-samarbejdet dermed hovedsagelig kommunikativt (Erdahl, 2011). Netredaktionen har således en distribuerende rolle. Dog sker det indimellem, at journalisterne fra de forskellige platforme producerer historier til mere end én platform (særligt sport og krim-stof), hvor der dermed er tale om crossmedia-produktion.

\section{Konvergens: Redaktionsstrukturer og specialisering}

Konvergensstrategierne og den måde, hvorpå mediehusene har opbygget en struktur for produktion og distribution af journalistisk stof på flere platforme, tegner et billede af fire former for strukturelle inddelinger i organiseringen af mediehuset, som overlapper på kryds og tværs, og som ligeledes er gensidigt forbundne. For det første ses en mediær organisering, hvor nyheder produceres til forskellige medieplatforme. For det andet ses en indholdsmæssig organisering, hvor nyheder produceres inden for forskellige emneområder. For det tredje kan vi se en organisering af produktion i forskellige journalistiske genrer, og sluttelig ses en redaktion med organisering af produktionen til bestemte målgrupper, både geografiske og emnemæssige.

Den gensidige forbundethed består i, at den genremæssige organisering eksempelvis også kan ses som en mediær organisering (når en bestemt medieplatform associeres med nyhedsproduktion), og at den indholdsmæssige organisering også henvender sig til bestemte målgrupper og derfor kan siges at være geografisk eller nichemæssig. Det kan derfor være svært analytisk at adskille de forskellige organiseringer, men ikke desto mindre er de nyttige i arbejdet med at opbygge en forståelse af strukturen af den netjournalistiske praksis i mediehuse med flere platforme i kraft af de forskellige specialiseringer. 
I relation til journalisternes professionalisering, specialisering og differentiering (se også Slaatta, 2003) kan man altså se dette i en række forskellige former i de tre mediehuse, og disse former for specialisering kan også forandre sig over tid. Således kan journalister være genremæssigt specialiseret, hvor de har udviklet en professionel specialisering i eksempelvis featurefortælling eller nyheder. De kan også være specialiserede i et bestemt stofområde såsom sport eller erhverv eller i det lydmæssige eller billedmæssige i den journalistiske, professionelle praksis, hvilket kan ses som en mediær specialisering.

At de strukturelle linjer organiserer nyhedsarbejdet på kryds og tværs synes at være et resultat af en historisk proces, hvor nye medieplatforme har ført til nye inddelinger, uden at de 'gamle', strukturelle linjer nødvendigvis er forsvundet. Den øgede kompleksitet og differentiering i form af nye platforme, flere nichesites og skellet mellem produktion og distribution manifesteret i nyhedsrummets fysiske organisering afspejler sig således i den journalistiske praksis.

Dermed kan vi også forstå den stigende konvergens og det stigende crossmedia-samarbejde i mediehusene på den måde, at strategier med crossmedia som mål måske nok slækker på én type specialisering, men til gengæld styrker en anden. Ved konvergens erstattes den mediære specialisering (i print, tv, net eller radio) således med et fokus på crossmedia-samarbejde, men der er behov for at analysere, hvad disse former for organisering betyder for det journalistiske nyhedsarbejde på netredaktionerne, og hvordan de ændrer eller fastholder hierarkier i nyhedsrummet. En sådan analyse præsenteres i det følgende.

\section{Den usynlige mur}

Som figurerne illustrerede, går trafikken af nyhedsstof hovedsagelig den ene vej. En historie fra TV Avisen må ofte først publiceres på Dr.dk en times tid, før TV Avisen går i luften. Når en historie er ude på Dr.dk, er det altså ikke længere en nyhed nyheden er blevet 'gammel' og må videreudvikles. Det sker dog, at de andre platforme fatter interesse for en nyhed, som starter på netredaktionen, men i et sådant tilfælde viser observatio- 
nerne, at det er TV Avisens medarbejdere, som bestemmer, hvordan og hvornår nyheden skal publiceres.

Også mellem radio og net er der et skel, selvom forskellene mellem de to medieplatforme af mange blev beskrevet som mindre end mellem tv og net (men ligesom på Politiken kan de forskellige medieplatforme holde på informationerne, indtil de selv har publiceret nyheden).

Dr.dk har en række af leveringsaftaler med andre platforme og DR's magasiner om at levere et bestemt antal artikler til Dr.dk om dagen. Det betyder, at DR Udland, eksempelvis ved at få en medarbejder fra netredaktionen, forpligter sig til at levere denne journalists årsværk til nettet. Men denne journalist er naturligvis også inkluderet i den almindelige produktion til radioplatformen, og derfor må Dr.dk ofte beklage sig over, at man ikke får, hvad man er blevet lovet.

Som en journalist forklarer, opfattes netredaktionen af resten af huset som et slags 'serviceorgan', man kan bruge, hvis en nyhed også skal publiceres på Dr.dk. Journalisterne fra andre platforme skal nemlig publicere et vist antal nyheder på nettet også, og her kan de - ofte fordi de er pressede - ty til at få journalisterne fra netredaktionen til at hjælpe med at gøre eksempelvis et tv-indslag til en netartikel. Følgende citat eksemplificerer dette.

"Der var en holdning blandt dem fra radio og tv om, at hvis man havde noget, der skulle ud, så kunne man lige få dem på netredaktionen til at skrive. Der er blevet en bedre forståelse af, hvad det er, vi sidder og laver, specielt fordi der er kommet mange fra de andre platforme på nettet også. I gamle dage, eller bare for to år siden, var der sådan en kile ned igennem lokalet. Dem fra tv, de snakkede ikke med dem fra radio og omvendt. Og dem på nettet vidste ingen rigtig, hvad egentlig sad og lavede. Og det har vi så forsøgt med Update, men jeg synes ikke, vi er kommet tættere på hinanden. Det går for langsomt, fordi de skal have billeder på."

Citatet illustrerer, at 'den usynlige mur' - her beskrevet som en "kile ned igennem lokalet" - synes at være blevet mindre i form af, at journalisterne fra andre medieplatforme nu bedre ved, hvad netredaktionen laver. Samtidig ser vi, at tv sættes lig med det langsomme, og citatet belyser endvidere det hierarki, vi ser 
i produktionen af nyheder, hvor netredaktionen associeres med distributionen og holdes ude af produktionen ved, at de andre redaktioner kan "holde informationer tilbage". Det betyder, at netmedarbejderne, når de får nys om en god historie, eksempelvis i DR, ofte er nødt til selv at finde den i DR's mediearkiv og skrive historien af fra enten tv-klippet eller radioindslaget. Som denne journalist, som både har arbejdet for net og radio, forklarer:

"På Radioen, når man har en kilde, kunne man godt vente en time med at sige det til Dr.dk, for vi skulle jo lige have den ud først. Det kører stadig sådan lidt. Vi har stadig sådan lidt, at man holder på sine ting. Radioavisen behøver heller ikke lige sige noget, før Dr.dk er ude med det. Og tv har jo kun to udsendelser, så de vil helst ikke, at vi siger noget. Der må vi publicere noget klokken fem. De burde være bedre til at orientere, hvem er det, vi har på, hvilke kilder osv. For så kan vi sidde herovre hos os og så have det klar også."

Hvad handler dette hemmelighedskræmmeri i virkeligheden om? Hvorfor er det, at netredaktionen ikke "må sige noget"? Forklaringen på dette skal findes hos konkurrenterne uden for huset. Det er vigtigt for TV Avisen, at den konkurrerende kanal TV 2 ikke får mulighed for at få nys om den samme historie, så DR ikke 'mister' sine eksklusive historier.

Grunden til den usynlige mur er, at der blandt journalisterne foregår en implicit kamp om retten til at producere. Både i DR og i Politikens Hus ser vi, hvordan den usynlige mur manifesterer sig i ganske bestemte hierarkier, og at disse kan forstås ud fra mediehusets og redaktionernes relationer til andre mediehuse og redaktioner.

Et eksempel på dette kan ses i vigtigheden af at få sin byline på de journalistiske artikler. Også her kan findes en forklaring på modstanden mod konvergensstrategierne og det tværmediale samarbejde, idet bylines teoretisk kan ses som symbolske goder, der dermed fordeles via citathistorier og distributionen af journalistisk stof på tværs af platforme og medier (Schultz, 2006; Hartley, 2011).

Journalisterne på netredaktionen oplever (ligesom i DR), at kollegaerne fra avisplatformen holder informationer tilbage for 
netmedarbejderne, hvilket fungerer som en sten i skoen for strategierne om tværmedialt samarbejde på tværs af platforme. En journalist fortalte i et interview, hvordan han i en samtale med en af avisernes journalister om en historie oplever, at avisens journalist insisterer på, at nyheden ikke kan skrives, før der er kommet flere informationer. Da netjournalisten bekræfter over for avisjournalisten, at det "blot er til baggrund", og at "hvis han har tænkt sig at skrive den til avisen den kommende dag, så kan den sagtens vente på nettet”, ændrer tonen sig, og pludselig er det en nyhed med masser af detaljer, citater og research. Følgende citat illustrerer avisens tilbageholdenhed over for netplatformen og omvendt:

"Folk skal have en respekt for hinandens medier, men man respekterer ikke det, man ikke kender eller forstår. Og det er jo ikke kun journalisternes skyld, for netredaktionen har også som samlet gruppe været meget beskyttende over for sig selv og holdt informationen tilbage. Og omvendt har avisens journalister holdt deres vinkel tilbage, så den kunne komme i avisen og også blive nævnt i Radioavisen om morgenen, som er dette evige succeskriterium på avisen. Det kan jeg også mærke på avisjournalisterne, for på den ene side synes de, at de fylder for lidt på netavisen, men omvendt så kunne de ikke drømme om at sende den ud på nettet, inden den har haft sin radioavis-chance. Så de vil gerne på nettet, men bare først, når det passer dem. Og der ligger en læreproces i, at man ikke kan få det hele."

Citatet viser flere interessante ting. For det første at det er muligheden for at blive citeret $\mathrm{i}$ andre medier, der er humlen $\mathrm{i}$ envejstrafikken mellem moderplatform og netplatform. Således bør forholdet mellem net og avis eller net og tv-avis i en given medieorganisation ses i forhold til selve medieoffentligheden og nyhedskredsløbet og medieorganisationernes positioner i nyhedsrummet. I Tunstalls studie (1971) så vi, at korrespondenterne kunne tilbageholde informationer for at publicere dem på et gunstigt tidspunkt, så andre medier kan tænkes at følge efter. Her foregår altså ligesom blandt Tunstalls specialister en kamp om at blive citeret. Men i Politikens tilfælde indikerer observationerne, at en publicering på netmediet, og specielt tidspunktet 
det sker på, dermed kan 'ødelægge' modermediets chancer for at blive citeret af andre medier.

\section{Lillebrorsyndromet}

“Vi er lidt som en lillebror, der bare må arve alt det gamle tøj. Men på nogle redaktioner, så har de dedikeret en bestemt medarbejder til online. Jeg hørte fra en kollega i et mediehus i Finland, at dér skulle de først lave noget til online. Men prøv at få en tv-aviseller en radioavis-journalist til at lave noget først til online - det er helt usandsynligt. Men det ville jo gøre, at vi kunne være hurtigere. Men hvis jeg selv sad på Radioavisen, så ville jeg også lave onlineversionen til sidst - det er jo en form for rovdrift på den enkelte medarbejder, og kvaliteten på produktet må da blive dårligere. Men hvis dem, der laver tv, hvor de før havde lydmand og alt muligt, nu også skal lave radio og online."

Citatet stammer fra et interview med en netjournalist fra Danmarks Radio foretaget i 2009. Citatet indrammer det fænomen, vi kan betegne som 'lillebrorsyndromet', en betegnelse for en ganske bestemt logik i mediehusene, som angiver nogle produktionshierarkier inden for mediehusets mure. At den usynlige mur opstår, kan forstås med udgangspunkt i disse hierarkier, der betyder, at forskellige journalistiske genrer og platforme har forskellige positioner og anerkendes forskelligt af journalisterne.

I Politikens Hus ser vi, hvordan medarbejdere fra Pol.dk til stor frustration kan se deres historier omskrevet af en af avisens journalister med de samme kilder, men uden netjournalistens byline på artiklen. Det samme gælder historier i nyhedsbåndet på toppen af hver historie i den trykte avis - her noterer netjournalisterne sig, at avisen til tider vælger en Ritzau-nyhed, selvom samme nyhed ligger på nettet, skrevet og researchet af nettets journalister. At gøre opmærksom på sine historier over for avisen ses af netjournalisterne som en slags 'tiggergang' hos avisen, og derfor lægger de ofte vægt på, at det ikke er et succeskriterium at se sig selv i den trykte avis. Og kun få tager turen ned i den anden ende af huset for at gøre opmærksom på deres historier på nettet: 
"Når jeg har lavet en historie, som egner sig til avisen, så går jeg de der tre skridt ned og siger: den her historie skal vi have $i$ morgen. Og så om ikke andet får jeg toppen i båndet, de der tre spalter, der ligger i toppen. Og det tror jeg, at jeg gør meget mere end de andre her på nettet. Jeg har det sådan lidt, ej det her, det er vigtigt, det SKAL stå i avisen også, hvor jeg tror, at nogle af de andre ikke synes, det er vigtigt, at den kommer i avisen."

Avisen ses som organet for de vigtige historier, mens nettet sagtens kan indeholde mindre vigtige nyheder. Og placeringen har også en betydning. På nettet skal man altså kæmpe for at få en reel artikel i avisen, mens man ofte kan få sin netnyhed i nyhedsbåndet foroven i den trykte avis. Når en netredaktion således bringer såkaldte 'vigtige' historier fra avisen, men det samme ikke sker den anden vej, bekræftes netredaktionens position som 'lillebror' i mediehuset.

Og nogle redaktioner på den trykte avis synes at have som princip ikke at bringe stof fra netplatformen. Eksempelvis dækkede en netjournalist nogle aktioner i et kunst-auktionshus. Journalisten skrev historierne til kultursitet, og journalisten mente efter mange års kendskab til avisens kultursektion, at dette måtte være en god historie for avisen. Han undrede sig derfor blandt kollegaerne på netredaktionen over, at avisens kulturredaktører "ikke engang" tog den som note. At netjournalisten allerede her forventede, at det "i det mindste" ville blive en note, viser, at også kategorier af nyheder afspejler relationelle positioner i nyhedsrummet. I avisen udgøres noterne af Ritzau-stof, mens netjournalisterne synes, at en god egenhistorie bør have en 'finere' placering end det. En kollega på netredaktionen fortæller ham, at man på avisens kulturredaktion har et princip om ikke at bringe historier, der har været publiceret på nettet. Man vil hellere tage noter fra Ritzau frem for netredaktionens journalistiske artikler ud fra argumentet om, at avisen ikke bør eller skal tage stof, som har været givet væk gratis på Pol.dk. Dette siger ganske meget om netplatformens position, både relationelt i forhold til avisen og $\mathrm{i}$ forhold til Ritzau. Netredaktionen ses som nederst i hierarkiet, endda under Ritzau, selvom netjournalisterne og avisens journalister er kollegaer, og Ritzau er et helt eksternt medie (som JP/ Politikens Hus godt nok er medejer af). 
Da projekt 'vi skruer op for nettet' skulle præsenteres for Nordjyskes redaktioner, var 'gratis-argumentet' ligeledes present. Og den måde, netredaktionens opgaver beskrives på over for aviskollegaerne, siger ganske meget om, hvad journalister og redaktører implicit forstår som "'små' historier og 'store' historier. De 'små' historier sættes lig med citathistorier, som man godt kan give væk gratis, mens de 'større' historier er egenproducerede og forbeholdt avisen, eller i DR's tilfælde TV Avisen.

Dette angiver netredaktionens rolle som distribuerende og forsikrer kollegaerne fra de andre platforme om, at de stadig har den producerende rolle i huset. På besøgsturene rundt på Nordjyskes lokalredaktioner bliver det igen og igen bekræftet, at "nettet ikke er et medie, som opdyrker egne historier". Og det fremgår af det skriftlige oplæg, at nethistorier og avishistorier ikke har samme status:

"Der er mange små, let-lavede nyheder, der ikke har en logisk ejermand i vort redaktionelle system, eller som ikke er store nok til at blive sat på dagsordenen i en indholdsgruppe, men som alligevel egner sig fremragende som nyhed på nettet."

Manual netjournalistik, Nordjyske.

Vi ser i citatet, at der skelnes mellem små og store nyheder, hvor de store knyttes til avisen, mens netplatformen også kan publicere mindre historier. Avisen knyttes omvendt til det 'tunge'. Og til det, hvor der er brugt ekstra tid og kræfter på at opdyrke egne historier og på at skrive dem godt - den producerende rolle. Som det ses i denne beskrivelse af, hvornår en historie skal "gemmes" til det trykte medie;

"I de tilfælde, hvor man gemmer stof til den næste dags avisudgivelse, vil det hovedsagelig være for at have forsidestof og/ eller gode læseoplevelser i form af baggrund og reportage. Eksempelvis:

Når vi laver et større stykke planlagt journalistik (INDSIGT, serier o.l.).

Når vi har diskuteret en historie grundigt og vurderet, at vi helt sikkert har den solo. 
Når vi vurderer, at en bestemt historie egner sig bedst til printmediet".

Manual netjournalistik, Nordjyske.

\section{Konklusion - nye produktions- og distributionshierarkier?}

Vi har set, at de forskellige mediehuse har indrettet sig forskelligt med betydning for, hvor meget indhold der produceres centralt fra netredaktionen, og hvor meget af indholdsproduktionen der er decentraliseret ud til andre medieplatforme og emnemæssige redaktioner internt i mediehuset. De tre cases er forskellige netop på dette punkt, og de forskellige modeller kan illustreres i nedenstående figur, hvor pilene under DR og Nordjyske også angiver en bevægelse i den periode, jeg har fulgt netredaktionerne.

Opsummerende definerer moderplatform og netplatform sig i modsætningen til hinanden. Dog viser observationerne i Politikens Hus, at netplatformen ses som separat og som selvstændig platform. Modsætningen illustrerer Pol.dk's placering på kontinuummet og placerer dem nærmest den separate pol, hvor netplatform og avisplatform ses som adskilte størrelser i den daglige journalistiske produktion. DR og Nordjyske er således langt mere konvergerede i deres praksis.

Etableringen af DR's nyhedsredaktion i 2008 medfører, at fra at være delvis separat og delvis konvergeret går DR det ekstra skridt, og ved at øge crossmedia-produktionen gør de mediehuset endnu mere konvergeret. I Nyhedsredaktionen i DR skulle en del af de selvsamme medarbejdere stadig producere til Dr.dk, men planen er også, at de skal bidrage til de andre medieplatforme hos DR. DR styrker den genremæssige organisering, idet man får nyhedsredaktionen og alt det andet. Regioner opretholder deres levering til de forskellige redaktioner og herunder også til Dr.dk, som de resterende medarbejdere på Dr.dk, der ikke flyttes til nyhedsredaktionen, har ansvar for at placere på sitet. Hvor de var både producerende og distribuerende, bliver de i højere grad kun distribuerende. 
Figur 4. Kontinuum over casenes placering i relation til distribution og produktion af nyheder

POLITIKEN

SEPARAT

SEPARAT/KONVERGERET

KONVERGERET

I den ende af kontinuummet vil man finde den mest mediærspecialiserede platform, idet mediehuset som regel har valgt at adskille netredaktionen og gøre den til en separat redaktion med egne medarbejdere, som ikke også producerer til andre medieplatforme i huset. I den modsatte ende finder man netredaktionen, der i høj grad er integreret i resten af mediehusets produktion. Sjældent producerer journalisterne til kun én redaktion. De er som oftest specialiseret i bestemte emner og fagområder, og selve nyhedsarbejdet til netplatformen har karakter af distribution af indhold fra andre medieplatforme i huset.

Dr.dk går dermed fra et være i en midterposition på kontinuummet over separat vs. integreret model til en mere konvergeret position. At Politikens netredaktion er separat, betyder således, at netjournalisterne i højere grad er producerende sammenlignet med de to andre mediehuse, selvom de internt i huset i kampen mod avisplatformen ses som distribuerende.

Og hvad har dette af betydning for de journalistiske hierarkier, vi ser i mediehusene med betydning for netjournalisters mulighed for specialisering?

Ovenfor har vi endvidere $\mathrm{i}$ alle tre mediehuse set en implicit og uudtalt regel på feltet om, at netjournalisterne ikke er producerende, men i højere grad distribuerende. Den producerende doxa 
på feltet holder netjournalistikken i en 'domineret' position på feltet. Dette har jeg i artiklen betegnet som 'lillebrorsyndromet'. Netredaktionerne er med deres distribuerende rolle udelukket fra den symbolske udveksling af værdi, der består i, at medierne citerer hinanden. Kontinuummet ovenfor angiver, hvordan der dog også er forskel på de tre cases. Groft sagt synes en styrkelse af crossmedia-samarbejdet at gøre netredaktionerne mere distribuerende.

Citathistorier bekræfter de sociale bånd, der knytter de forskellige positioner i nyhedsrummet sammen (Schultz, 2006). De producerende medier ses som de givende, mens netredaktionerne må se sig selv som de modtagende og således i en domineret position. Som lillebroderen, der konstant må arve storbrors aflagte tøj og finde sig i, at mor og far bestemmer, hvor længe han må være ude, selvom storebror får lov at være længe ude. Den producerende praksislogik kan altså ses som en 'nedarvet' logik fra feltet. En logik, der manifesterer sig som en 'usynlig mur' i newsroom og konjunkturerne af en opdeling i A- og B-journalister, idet 'modermedierne' ikke uden kamp giver slip på deres mediære og indholdsmæssige specialiseringer, og netjournalisterne kæmper for at opnå anerkendelse for andre former for specialisering, i takt med at mediehusets konvergensstrategier udvisker den mediære specialisering.

\section{REFERENCER}

Boczkowski, P. (2009a). Rethinking Hard and Soft News Production: From Common Ground to Divergent Paths, in Journal of Communication 59, pp. 98-116.

Boczkowski, P. (2004b). Digitizing the news, Innovation in online newspapers. Cambridge, MA: MIT Press.

Cottle, S. og Ashton, M. (1999). From BBC Newsroom to BBC Newscentre: On Changing Technology and Journalist Practices. Convergence: The International Journal of Research into New Media Technologies, September 5: pp. 22-43.

Deuze, M. (2004). What is multimedia journalism? Journalism Studies, 5(2): pp. 139-152.

Deuze, M. (2007). Media Work. Cambridge: Polity Press.

Dailey. L., Demo, L. og Spillman, M. (2005). The convergence continuum: 
A model for studying collaboration between media newsrooms, Atlantic Journal of Communication, 13(3): pp. 150-168.

Domingo (2006). Inventing online journalism: Development of the Internet as a news medium in four Catalan newsrooms. Ph.D. dissertation, Universitat Autònoma de Barcelona. July 2006.

Erdahl, J.I. (2011). Coming to Terms with Convergence Journalism: CrossMedia as a Theoretical and Analytical Concept, Convergence May 2011, vol. 17, no. 2: pp. 213-223.

Fagerjord, A. og Storsul, T. (2007). Questioning convergence. In: Storsul, T. and Stuedahl, D. (eds.). Ambivalence Towards Convergence. Gothenburg: Nordicom, pp. 19-31.

Hartley, J. (2011) Radikalisering af Kampzonen, en analyse af netjournalistisk praksis medlemme idealer og publikum, Ph.d. afhandling, Roskilde Universitet.

Jenkins, H. (2006). Convergence Culture: Where Old and New Media Collide. New York: New York University Press.

Kung, L., Kröll, A., Ripken, B. og Walker, M. (1999). Impact of the digital revolution on the media and Communication Industries. Javnost: the public, 6(3), pp. 29-47.

Lund, A. B. (2001). Invitation til mediesociologi. Dansk Sociologi nr. 2, 12. årgang. Dansk Sociologiforening.

Mortensen, Frands (2000). Dansk medieforskning igennem de seneste 30 år. I: MedieKultur 31.

Norman, H. (2008). Flerkanalspublicering och journalistisk produktion. I: Nyhetsfabrikken, red. af Gunnar Nygren, Studentlitteratur: Sverige.

Pavlik, J. V. (2001). Journalism and new media. New York: Columbia University Press.

Quinn, S. (2005). Convergence's fundamental question, Journalism Studies, Volume 6, Issue 1, 2005.

Schultz, I. (2006). Bag nyhederne - voerdier, idealer og praksis. Forlaget Samfundslitteratur.

Tunstall, J. (1971). Journalists at work, specialist correspondents: their news organizations, news sources, and competitor-colleagues, Sage Publications.

Yin, R. K. (2009). Case Study Research: Design and Methods: (Applied Social Research Methods, Volume 5). 